\title{
REVIEW
}

\section{Are guitarfishes the next sawfishes? Extinction risk and an urgent call for conservation action}

\author{
Alec B. M. Moore* \\ RSK Environment Ltd., Helsby, Cheshire WA6 0AR, UK
}

\begin{abstract}
Focusing on the most critical conservation priorities to prevent extinctions risks missing declines of lower priority taxa that may become tomorrow's emergency. Sawfishes (5 species) underwent catastrophic but largely unnoticed global declines in the latter part of the 20th century, and are now the subject of intensive research and conservation efforts. Guitarfishes (at least 55 species) share many characteristics with sawfishes: they are shark-like batoids with an often large body, prefer sedimentary habitats in warm shallow coastal waters exposed to intensive fisheries, and have high value fins and good quality meat. Guitarfishes represent a unique element of evolution and biodiversity and are vital components of complex coastal socio-ecological systems. Existing global IUCN Red List of Threatened Species assessments for nearly $60 \%$ of guitarfish species are 10 or more years old, and over $70 \%$ of species are either in threatened categories or Data Deficient. Recently described taxa not yet assessed include those likely to be at risk of extinction. Severe declines and localised extinctions have already been reported for guitarfishes. In notable contrast to sawfishes, total extinction of several guitarfish species is plausible given small distributions occurring solely in developing or least developed countries where conservation is highly challenging. Furthermore, species identification of guitarfishes is often problematic and they may lack the appeal often needed to promote conservation. To ensure that they do not follow the same trajectory as sawfishes, there is an urgent need for comprehensive and coordinated action on guitarfishes, which in many cases could integrate with sawfish conservation efforts.
\end{abstract}

KEY WORDS: Elasmobranch · Extinction · Fisheries · Conservation · Glaucostegidae $\cdot$ Rhinidae Rhinobatidae $\cdot$ Trygonorrhinidae

\section{INTRODUCTION}

Conservationists tend to tackle the most urgent priorities to prevent extinction of the rarest (and often the most charismatic) species. Less conservation effort is directed at other taxa, but this risks missing alarming declines that may be of ecological significance. For example in Europe, the abundance of common birds such as the house sparrow Passer domesticus has declined dramatically, while that of rarer species such as the grey heron Ardea cinerea has increased (Inger et al. 2015). Furthermore, allocating the most resources to taxa with the greatest risk of extinction may not be the most efficient way to

${ }^{*}$ Corresponding author: amoore@rsk.co.uk promote recovery or reduce global extinctions, as some of the most threatened species will require vast conservation effort with a small chance of success (Possingham et al. 2002). Therefore, focusing on today's critical priorities risks losing sight of those species that may well turn out to be tomorrow's emergencies.

Once collapsed, many marine fish populations do not recover rapidly, if at all, even with reduction in fishing pressure (Hutchings \& Reynolds 2004). Using the precautionary principle, prevention of collapses in the first place is therefore essential. One such example of marine fish population collapse is that of the sawfishes (Pristidae, 5 species). These are large

() The author 2017. Open Access under Creative Commons by Attribution Licence. Use, distribution and reproduction are unrestricted. Authors and original publication must be credited. 
to massive (3.2 to $7 \mathrm{~m}$ maximum total length, TL) and highly recognisable shark-like batoids that were previously common to abundant in soft-bottom habitats of shallow, warm waters worldwide, often enjoying close associations with human culture through mythology and folklore (Harrison \& Dulvy 2014). Despite these factors, research on sawfishes was conspicuously lacking, and one of the first focused field studies was also that which documented their disastrous fisheries-driven extinction in Lake Nicaragua (Thorson 1982). Even with this clear example of vulnerability and a significant growth in elasmobranch research in ensuing decades, catastrophic global declines went almost unnoticed, with a notable exception in the grey literature: 'The Shark Specialist Group is becoming increasingly concerned about widespread reports...of an apparent serious decline over the past few decades of formerly healthy populations of all species of sawfish' (Anonymous 1996).

Following this, conservation-driven research started in the USA and Australia, alongside efforts to list sawfishes on national and international conservation policy such as the USA Endangered Species Act and the Convention on International Trade in Endangered Species (Carlson et al. 2013). However, it was not until 2014 that a co-ordinated global conservation strategy was published, along with research from developing nations that makes up the vast majority of the range of sawfishes (Harrison \& Dulvy 2014). Thus, over 3 decades had passed between explicit evidence of extinction risk and a truly global response, by which time sawfishes had all but vanished from vast areas encompassing local, regional and global scales (Moore 2015, Dulvy et al. 2016, Leeney \& Downing 2016). All 5 species of sawfish are now considered Critically Endangered or Endangered on the IUCN Red List of Threatened Species (RL) (Carlson et al. 2013, D'Anastasi et al. 2013, Kyne et al. 2013a,b, Simpfendorfer 2013), and their realistic recovery in huge parts of their former range is highly unlikely.

In the wider field of conservation biology, embracing and acknowledging failure has been argued as being a fundamental requirement for success in order to improve learning, enhance innovation and promote adaptive management (Redford \& Taber 2000, Knight 2009). It would be difficult to argue that the sawfish story represents anything other than a comprehensive, collective failure by scientists and managers to recognise, document and address the problem before it was too late to meaningfully intervene, for most of the world. As the current paper explains, lessons learned from the sawfish story have major relevance to another group of shark-like batoids, the guitarfishes.

The definition of guitarfish, at least for a biologist, is straightforward. As clarified in a recent major taxonomic revision (Last et al. 2016a), guitarfishes are batoid elasmobranchs comprising 4 families (Rhinidae, 10 species; Rhinobatidae, 31 species; Glaucostegidae, 6 species; and Trygonorrhinidae, 8 species; see Table 1). Together with the sawfishes, these comprise the Order Rhinopristiformes (Last et al. 2016a). For non-biologists, however, guitarfishes suffer from a confusing array of often overlapping English vernacular names. As examples, giant guitarfish is a term widely used for both Rhynchobatus (Rhinidae) and Glaucostegidae (also known as shovelnose rays); Rhynchobatus are sometimes known as wedgefish in Australia and this term is proposed for the wider family Rhinidae, even though the remainder of its genera (Rhina and Rhynchorhina) lack a wedge-shaped snout. Common names even include reference to sharks, such as the generic term guitar shark, lesser sand shark (Acroteriobatus annulatus) and shark ray (Rhina ancylostoma). This lack of nomenclatural clarity and identity may prove a barrier to public engagement, conservation policy and fisheries management, and suggests that the adoption of a standard name, the guitarfishes, is worthwhile.

While guitarfishes have already been identified as being amongst the most vulnerable of elasmobranch families after the sawfishes (Dulvy et al. 2014), they remain poorly known with little scientific or media attention. To relate the many similarities that sawfishes and guitarfishes share, and to identify what could be learned from the global decline of sawfishes, the purpose of the present study is 3-fold: (1) to outline why guitarfishes are important, and therefore worthy of conservation effort; (2) to review and compare broad extinction risk factors between sawfishes and guitarfishes; and (3) to provide an overview of existing global IUCN RL assessments of guitarfishes. This review concludes with an assessment of what lessons can be learned from the sawfish experience, and how these might be applied to guitarfishes.

\section{METHODS}

This paper attempts to reflect a synthesis of current knowledge (such as published literature) on guitarfishes, as well as identifying less tangible trends, gaps and opportunities observed by the author or discussed with colleagues over several years researching elasmobranch biodiversity, fisheries and conser- 
Table 1. Scientific and common names of described guitarfishes, their global IUCN Red List assessment status (as of 1 March 2017) and geographical distribution as per Last et al. (2016b). CR: Critically Endangered; EN: Endangered; VU: Vulnerable; NT: Near Threatened; LC: Least Concern; DD: Data Deficient; NE: Not Evaluated. N/A: not applicable. WIO/EIO/NIO: Western/Eastern/Northern Indian Ocean; WNP/ WCP/WSP: Western North/Central/South Pacific Ocean; ENP/ECP/ESP: Eastern North/Central/South Pacific Ocean; WNA/WCA/WSA:

Western North/Central/South Atlantic Ocean; ENA/ECA/ESA: Eastern North/Central/South Atlantic Ocean; MED: Mediterranean

$\begin{array}{lll}\text { Taxon } & \text { Common English } \\ \text { name(s) } & \begin{array}{c}\text { Red List Year Distribution } \\ \text { status assessed }\end{array}\end{array}$

\section{Family Rhinidae}

Rhina ancylostoma Bloch \& Schneider, 1801

Rhynchobatus australiae Whitley, 1939

Rhynchobatus cooki Last, Kyne \& Compagno, 2016 Rhynchobatus djiddensis (Forsskål, 1775)

Rhynchobatus immaculatus Last, Ho \& Chen, 2013

Rhynchobatus laevis (Bloch \& Schneider, 1801)

Rhynchobatus luebberti Ehrenbaum, 1915

Rhynchobatus palpebratus Compagno \& Last, 2008

Rhynchobatus springeri Compagno \& Last, 2010

Rhynchorhina mauritaniensis Séret \& Naylor, 2016

\section{Family Rhinobatidae}

Acroteriobatus annulatus (Müller \& Henle, 1841)

Acroteriobatus blochii (Müller \& Henle, 1841)

Acroteriobatus leucospilus (Norman, 1926)

Acroteriobatus ocellatus (Norman, 1926)

Acroteriobatus omanensis (Last, Henderson \& Naylor 2016)

Acroteriobatus salalah (Randall \& Compagno, 1995)

Acroteriobatus variegatus (Nair \& Lal Mohan, 1973)

Acroteriobatus zanzibarensis (Norman, 1926)

Pseudobatos glaucostigmus (Jordan \& Gilbert, 1883)

Pseudobatos horkelii (Müller \& Henle, 1841)

Pseudobatos lentiginosus (Garman, 1880)

Pseudobatos leucorhynchus (Günther, 1867)

Pseudobatos percellens (Walbaum, 1792)

Pseudobatos planiceps (Garman, 1880)

Pseudobatos prahli (Acero \& Franke, 1995)

Pseudobatos productus (Ayres, 1854)

Rhinobatos albomaculatus Norman, 1930

Rhinobatos annandalei Norman, 1926

Rhinobatos borneensis Last, Séret \& Naylor, 2016

Rhinobatos holcorhynchus Norman, 1922

Rhinobatos hynnicephalus Richardson, 1846

Rhinobatos irvinei Norman, 1931

Rhinobatos jimbaranensis Last, White \& Fahmi, 2006

Rhinobatos lionotus Norman, 1926

Rhinobatos nudidorsalis Last, Compagno \& Nakaya, 2004

Rhinobatos penggali Last, White \& Fahmi, 2006

Rhinobatos punctifer Compagno \& Randall, 1987

Rhinobatos rhinobatos (Linnaeus, 1758)

Rhinobatos sainsburyi Last, 2004

Rhinobatos schlegelii Müller \& Henle, 1841

Rhinobatos whitei Last, Corrigan \& Naylor, 2014

\section{Family Glaucostegidae}

Glaucostegus cemiculus (Geoffroy St. Hilaire, 1817)

Glaucostegus granulatus (Cuvier, 1829)

Glaucostegus halavi (Forsskål, 1775)

Glaucostegus obtusus (Müller \& Henle, 1841)

Glaucostegus thouin (Anonymous, 1798)

Glaucostegus typus (Bennett, 1830)
Shark ray

Bottlenose guitarfish

Clown wedgefish, roughnose wedgefish Giant guitarfish; white-spotted wedgefish

Taiwanese wedgefish

Smoothnose wedgefish

African wedgefish

Eyebrow wedgefish

Broad-nosed wedgefish

False shark ray

Lesser sand shark

Bluntnose guitarfish

Grayspotted guitarfish

Speckled guitarfish

Oman guitarfish

Salalah guitarfish

Stripenose guitarfish

Zanzibar guitarfish

Speckled guitarfish

Brazilian guitarfish

Freckled guitarfish

Whitesnout guitarfish

Southern guitarfish

Flathead guitarfish

Gorgona guitarfish

Shovelnose guitarfish

Whitespotted guitarfish

Annandale's guitarfish

Borneo shovelnose ray

Slender guitarfish

Ringstraked guitarfish

Spineback guitarfish

Jimbaran shovelnose ray

Smoothback guitarfish

Bareback shovelnose ray

Indonesian shovelnose ray

Spotted guitarfish

Common guitarfish

Goldeneye shovelnose ray

Brown guitarfish

Philippine guitarfish

Blackchin guitarfish

Granulated guitarfish

Halavi's guitarfish

Widenose guitarfish

Clubnose guitarfish

Giant shovelnose ray
VU

2015

VU

VU

VU

NE

VU

EN

NE

$\mathrm{VU}$

NE

LC

LC

DD

DD

NE

DD

DD

NT

DD

CR

NT

NT

NT

DD

DD

NT

$\mathrm{VU}$

DD

NE

DD

NT

$\mathrm{VU}$

VU

DD

NT

VU

DD

EN

LC

DD

NE

EN

VU

DD

VU

VU

VU
2003

2006

2006

N/A

2015

2006

N/A

2006

N/A

2006

2006

2008

2008

N/A

2006

2008

2006

2008

2007

2004

2006

2004

2004

2007

2014

2008

2008

N/A

2008

2006

2008

2006

2008

2006

2006

2004

2007

2015

2004

N/A

2007

2006

2008

2006

2006

2003
WIO, EIO, NIO, WSP, WCP, WNP WIO, EIO, NIO, WSP, WCP, WNP WCP WIO, NIO

WNP NIO, WNP ECA EIO, WSP, WCP NIO, EIO, WCP ECA

WIO, ESA

ESA

WIO

WIO

NIO

NIO

NIO

WIO

ECP

WSA

WCA, WNA

ECP

WSA, WCA

ECP, ESP

$\mathrm{ECP}$

ENP, ECP

ECA

NIO

WCP

WIO

WCP, WNP

ECA

EIO

NIO

WIO

EIO

NIO

ENA, MED, ECA

EIO, WCP

WNP

WNP

ENA, MED, ECA

NIO

NIO

NIO, WCP

NIO, EIO, WCP

NIO, EIO, WSP, WCP, WNP 
Table 1 (continued)

\begin{tabular}{|llccc|}
\hline Taxon & Common English name(s) & $\begin{array}{c}\text { Red List } \\
\text { status }\end{array}$ & $\begin{array}{c}\text { Year } \\
\text { assessed }\end{array}$ & Distribution \\
\hline Family Trygonorrhinidae & & & & \\
Aptychotrema rostrata (Shaw, 1794) & Eastern shovelnose ray & LC & 2015 & WSP \\
Aptychotrema timorensis Last, 2004 & Spotted shovelnose ray & VU & 2015 & WCP \\
Aptychotrema vincentiana (Haacke, 1885) & Western shovelnose ray & LC & 2015 & EIO \\
Trygonorrhina dumerilii (Castelnau, 1873) & Southern fiddler ray & LC & 2015 & EIO, WSP \\
Trygonorrhina fasciata Müller \& Henle, 1841 & Eastern fiddler ray & LC & 2015 & WSP \\
Zapteryx brevirostris (Müller \& Henle, 1841) & Shortnose guitarfish & VU & 2006 & WSA \\
Zapteryx exasperata (Jordan \& Gilbert, 1880) & Banded guitarfish & DD & 2015 & ENP, ECP \\
Zapteryx xyster Jordan \& Evermann, 1896 & Southern banded guitarfish & DD & 2008 & ECP \\
\hline
\end{tabular}

vation. Searches using taxonomic identifiers (for example 'guitarfish' and 'Rhynchobatus') were conducted in the first half of 2016 using resources such as Web of Science, in order to identify published data on those aspects of guitarfishes relevant to their ecology and conservation (such as distribution, fisheries and trade), especially in comparison to sawfishes. Scientific names used in the current paper are consistent with the recent revisions of Last et al. (2016a,b), which changed the nomenclature of several genera. Global IUCN RL assessments for all guitarfishes were downloaded on 1 March 2017 (IUCN 2016). The year in which the assessment was performed was used for analysis, as in some cases these were not published immediately, and in some cases, a more recent publication date reflected only nomenclatural changes (as per Last et al. 2016b), and not full re-assessment. While it is acknowledged that the RL process is ongoing and dynamic, the validity of RL assessments was reviewed based on their age: those performed in 2007 or before, and therefore beyond the 5 to $10 \mathrm{yr}$ aim of the IUCN for re-assessment of taxa (IUCN Species Survival Commission 2016) were considered out of date. The term 'Least Developed Countries' (LDC) is as defined by UNDESA (2016), i.e. 'lowincome countries confronting severe structural impediments to sustainable development', and is taken here as being a nation severely restricted in its ability to successfully conserve threatened marine fishes, including guitarfishes. Of particular relevance to the current paper (and to coastal elasmobranch conservation in general) are 3 large tropical marine regions whose entire coastline is made up of multiple LDCs ('LDC regions' hereafter): part of West Africa (Mauritania, Senegal, Gambia, Guinea Bissau, Guinea, Sierra Leone, Liberia), Gulf of Aden/southern Red Sea (Yemen, Somalia, Djibouti, Eritrea, Sudan) and the Southwest Indian Ocean (Madagascar, Mozambique, Tanzania, Comoros).

\section{WHY ARE GUITARFISH IMPORTANT?}

Guitarfishes are important components of coastal socio-ecological systems. They have provided a source of marine protein to coastal human communities since at least the Bronze Age (Uerpmann \& Uerpmann 2005), and continue to do so: Senegal, an LDC, reported to the FAO annual guitarfish landings averaging $1148 \mathrm{t} \mathrm{yr}^{-1}$ in the period 2004 to 2014 (FAO 2016). Other nations currently specifically reporting guitarfish landings include Pakistan, Indonesia, Libya, Benin and Palestine (FAO 2016). Guitarfishes can contribute to local economies through dive ecotourism (African Dive Adventures 2014) and recreational angling (Dunlop et al. 2013), and to education as exhibits in public aquaria (Georgia Aquarium 2016). As relatively large and sometimes abundant benthic mesopredators, guitarfish have an important role in the trophic functioning of soft-sediment ecosystems (Kyne \& Bennett 2002). As many guitarfish are found associated with seagrasses (Vaudo \& Heithaus 2011), their presence presumably contributes to the healthy functioning of this habitat that is of very high ecosystem service value to humans (Campagne et al. 2015). Guitarfishes are important prey items to non-human apex predators vital to ecosystem functioning, such as to bull (Carcharhinus leucas), sevengill (Notorynchus cepedianus), and great hammerhead (Sphyrna mokarran) sharks off southern Africa (Cliff \& Dudley 1991, Ebert 1991, Cliff 1995). This ecosystem importance also extends downward, with guitarfish being shown to consume up to $77 \%$ of the annual benthic invertebrate production of a lagoon in South Africa (Harris et al. 1988). Some species appear to have a specialised diet, such as the banded guitarfish Zapteryx exasperata in the Gulf of California, which consumes mainly benthic fish (Blanco-Parra et al. 2012). Preliminary stable isotope studies have also hinted at a more pelagic role in the 
ecosystem for some guitarfish (i.e. bowmouth guitarfish Rhina ancylostoma) despite their dorso-ventrally flattened morphology (Borrell et al. 2011).

Guitarfishes also have high intrinsic value as a unique example of biodiversity, adaptation and vast evolutionary lineage. Rhinobatids appeared in the early Jurassic, and the extant sawfishes arose from them (Wueringer et al. 2009). Guitarfishes provide habitat to a large suite of unique fauna in the form of highly host-specific parasites (e.g. Bullard \& Dippenaar 2003). Hydrodynamic studies of guitarfish nostrils have shown an arrangement of vertical structures similar to those on aircraft wings that may enhance olfaction and reduce the energetic costs of swimming (Agbesi et al. 2016), and the giant guitarfish Rhynchobatus djiddensis has the ability to protect its eye by a degree of retraction that is probably one of the largest among all vertebrates (Tomita et al. 2016).

\section{EXTINCTION RISK FACTORS: COMPARISON OF SAWFISHES AND GUITARFISHES}

\section{Economic value}

A key extinction risk factor to fish species is economic and food value to humans: those that are highly prized by humans, especially those that are large (e.g. sturgeons Acipenser spp. and bluefin tuna Thunnus maccoyii), are often most at risk. For both sawfishes and guitarfishes their high economic and food value likely presents a similar factor in extinction risk in terms of having targeted fisheries and retention of any bycatch. The fins of both guitarfishes and sawfishes have long been known to be of exceptionally high value in the shark fin trade. In the second half of the 20th century, bowmouth guitarfish Rhina ancylostoma fins were 'the choicest and most expensive' in the Philippines (Herre 1954, p. 386), and Rhynchobatus fins were considered high value in India and Indonesia (James 1973, Keong 1996). Trade in high grade 'tongari' fins from Rhynchobatus spp. was thought to be the main factor responsible for the doubling of the value of Indonesian fin exports to Hong Kong twice in the 1980s (1983 to 1984 and 1986 to 1987; Suzuki 2002). Keong (1996) reported that a set of fins from a single individual of Rhynchobatus spp. could attain around US\$396 $\mathrm{kg}^{-1}$. More recently, the fins of guitarfishes including Rhynchobatus and Rhina are considered by East Asian shark fin traders as being the sources of the best quality fin needles for consumption (Clarke et al. 2007). Targeting of Rhyn- chobatus for their fins occurs widely, such as in the Southwest Indian Ocean LDC region off northern Madagascar (Hopkins 2011), Mozambique (Pierce et al. 2008) and off Zanzibar, Tanzania, where this activity was believed by some fishers to have been driving declines (Schaeffer 2004). The extremely high value of Rhynchobatus fins in Indonesia has driven intensive targeted fisheries since the 1970s, with apparent localised depletions around Java, Sumatra, Kalimantan and Sulawesi (White \& Sommerville 2010). In Madagascar in 2014, guitarfish fins were around US\$70 $\mathrm{kg}^{-1}$, around twice as valuable as shark fins (Cripps et al. 2015). Blackchin guitarfish Glaucostegus cemiculus landed on the beach in The Gambia in 2014 always had their dorsal and caudal fins removed (Fig. 1); in 2007 their fins were reported as fetching around $€ 100 \mathrm{~kg}^{-1}$ in the region (Notarbartolo di Sciara 2016).

In addition to fins, guitarfish meat is of good quality (White \& McAuley 2003) and a highly conservative estimate of at least $5000 \mathrm{t}$ was landed in 2014, as reported by a handful of nations (FAO 2016). Meat is widely utilised both fresh (e.g. Rhynchobatus species

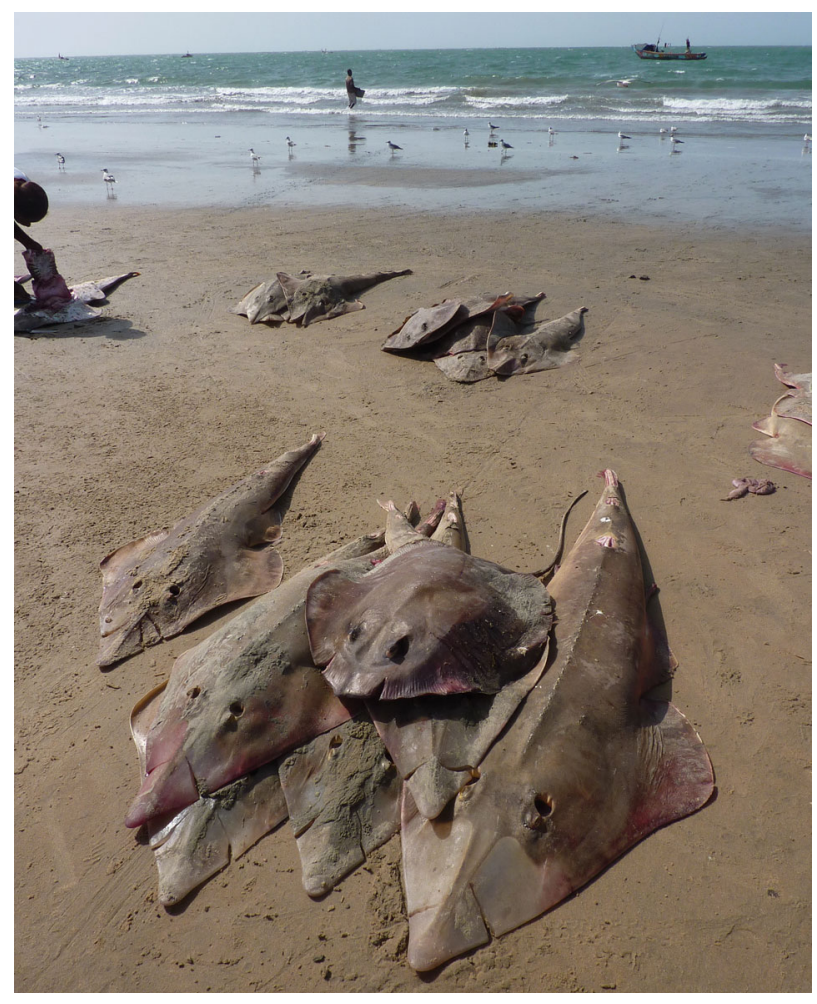

Fig. 1. Individuals of the Endangered blackchin guitarfish Glaucostegus cemiculus landed for salting and drying of meat, Ghana Town, The Gambia, March 2014. Dorsal and caudal fins have already been removed for separate onward sale. Daisy whipray Fontitrygon margarita also in foreground 
in fish markets of Kuwait in 2011, Fig. 2) and dried and salted, sometimes for export (G. cemiculus in The Gambia, author's pers. obs.). Furthermore, there is an as yet unquantified level of trade in other guitarfish products in Southeast Asia, including novel dishes made of head cartilage, and jewellery made from the dorsal thorns of Rhina ancylostoma (M. McDavitt pers. comm.).

The economic value of guitarfishes sustains illegal fishing activity, such as the retention of the prohibited and Critically Endangered Brazilian guitarfish Pseudobatos horkelii off Brazil (Alexandre de-Franco et al. 2012), and the retention of fins of several species in illegal fishing activity off northern Australia (Holmes et al. 2009).

\section{Habitat}

Habitat likely plays a key role in extinction vulnerability of elasmobranchs as it modifies exposure to fishing pressure. Soft-bottom habitats (such as sand, mud, seagrass and mangrove) are generally much easier for humans to fish with a range of demersal

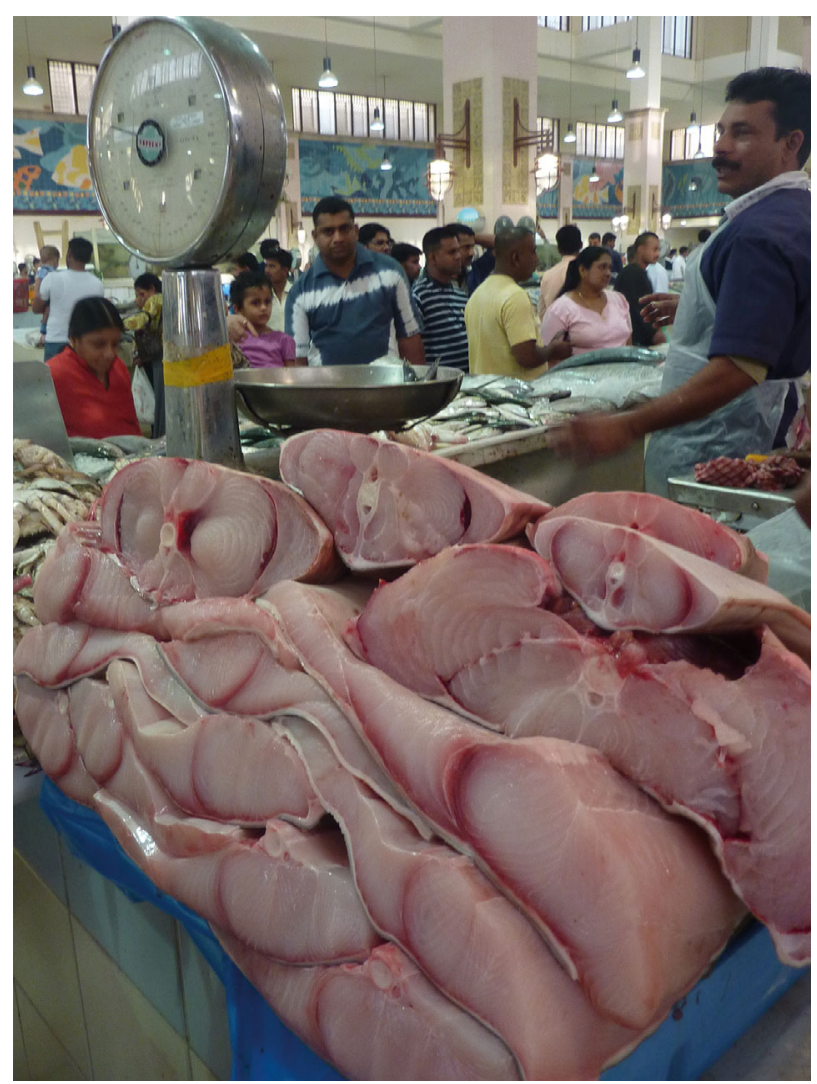

Fig. 2. Meat of large wedgefish Rhynchobatus spp. on sale in Sharq market, Kuwait, April 2011 gears such as trawls and gillnets compared to rocky or reef habitats, where gear loss or damage is a constraint. Habitat preference may at least partly explain why 2 morphologically similar, ambushpredator benthic sharks have such vastly different conservation status: over half of angel shark (Squatinidae) species, which favour soft-bottom habitats, are in RL threatened categories, while most species of wobbegong (Orectolobidae), which favour rocky and reef habitat, are 'Least Concern' (IUCN 2016). Some highly threatened elasmobranch species that were formerly common in a range of habitat types now only persist in habitat that provides refuge. An example is remnant populations of the skate species complex Dipturus spp. around the western British Isles, which appear to be afforded protection by seabed that is difficult to trawl (Shephard et al. 2012, Neat et al. 2015).

Sawfishes and most guitarfishes are likely to face broadly similar exposure to habitat-related extinction risk factors. Some species of sawfishes such as the largetooth sawfish Pristis pristis are reliant on freshwater habitat for at least some of their life cycle (Kyne et al. 2013a), and therefore significant habitat modification such as damming (in addition to fisheries) may present an extinction risk factor that guitarfishes, restricted to marine and estuarine habitat, are not exposed to. However, all species of sawfishes, and the vast majority of guitarfish species, are strongly associated with soft-bottom habitats in shallow $(<50 \mathrm{~m}$, but usually considerably less) warmtemperate to tropical coastal waters, which are exposed to intensive and expanding fisheries (Harrison \& Dulvy 2014, White \& Sommerville 2010), as well as widespread loss of mangrove and seagrass habitat (Valiela et al. 2001, Duke et al. 2007, Waycott et al. 2009). It is possible that not all guitarfish are limited to inshore soft-sediment habitat: for example, the southern banded guitarfish Zapteryx xyster may be reef-associated (Casper et al. 2009) and the bareback shovelnose ray Rhinobatos nudidorsalis is known only from deeper water $(125 \mathrm{~m})$ on a mid-ocean ridge (Compagno \& Marshall 2006a).

\section{Distribution}

The geographic distribution of marine species is thought to affect extinction risk. Some authors have proposed that a large range decreases vulnerability (Roberts \& Hawkins 1999), while others have more recently supported an alternative view of large range across multiple jurisdictions failing to mitigate risk, 
because of the need for effective international management (Dulvy et al. 2014, McClenachan et al. 2016).

While the majority of the range of sawfish distribution is in developing countries, all 5 sawfish species have at least part of their range in developed countries that currently afford a safe haven of effective protection: the USA (for smalltooth sawfish $P$. pectinata, Carlson et al. 2013) and Australia (for dwarf sawfish $P$. clavata, $P$. pristis, green sawfish $P$. zijsron and narrow sawfish Anoxypristis cuspidata; D'Anastasi et al. 2013, Kyne et al. 2013a,b, Simpfendorfer 2013). As such, none of the 5 sawfish species are currently likely to undergo total, global extinction. Most sawfish species also have vast historic ranges: for example $P$. zijsron has been recorded across the IndoWest Pacific from South Africa to Taiwan (Simpfendorfer 2013). This large distribution may provide an additional buffer against extinction, increasing the probability of individuals or as yet unknown remnant populations in remote or refuge areas.

In stark contrast, the known geographical distribution of many guitarfish species may increase global extinction risk. Several species are endemic (or only known from highly restricted distributions), or only a handful of specimens have been found (see 'IUCN Red List assessments; Data Deficient' below). Additionally, most guitarfish species are known only from developing or LDC nations where issues such as intensive fisheries and lack of fisheries management make any attempts at conservation highly challenging. Some guitarfish are affected by both of these risk factors: the recently described false shark ray Rhynchorhina mauritaniensis is known only from a handful of specimens from a restricted area in Mauritania (Séret \& Naylor 2016). There are warnings from similarly afflicted elasmobranch species: the stingaree Urolophus javanicus, known only from Java, has not been recorded for over $150 \mathrm{yr}$ and may be extinct (Last \& Marshall 2006).

\section{Size and morphology}

Extinction threat in extant marine systems is strongly associated with large body size (Payne et al. 2016), and numerous Critically Endangered marine fishes have a maximum reported TL of $2 \mathrm{~m}$ or more, such as sturgeons, southern bluefin tuna and giant sea bass Stereolepis gigas (IUCN 2016). While guitarfishes do not attain the size of the largest sawfish species (up to $7 \mathrm{~m} \mathrm{TL}$ ), a number of species exceed 2.5 to $3 \mathrm{~m}$ TL (e.g. Rhynchorhina mauritaniensis,
Rhina anclyostoma, white-spotted guitarfish Rhynchobatus australiae, Rhynchobatus djiddensis, clubnose guitarfish $G$. thouin and giant shovelnose ray $G$. typus; Last et al. 2016b), presenting significant extinction risk when combined with overfishing. While sawfishes and guitarfishes both share the same dorso-ventrally flattened body shape that makes them vulnerable to fisheries capture, guitarfishes lack the long tooth-studded rostrum that greatly increases the entanglement risk of sawfishes in net fisheries. This may partly explain the persistence of Rhynchobatus spp. catches in areas where sawfishes have all but disappeared, such as in eastern Indonesia (White \& Dharmadi 2007).

\section{Identification}

Correct identification of species is fundamental to effective management as biological parameters, and therefore vulnerabilities, can vary widely, even between closely related taxa that are similar in appearance. In most of their current global range, identification of sawfishes is relatively straightforward, given clear morphological differences between species (Last et al. 2016b). Conversely, the effective management of guitarfish fisheries is constrained by numerous difficulties in identification. In Brazil, processed landings of the protected and Critically Endangered Pseudobatos horkelii are difficult for enforcement agencies to distinguish from similar species (Alexandre de-Franco et al. 2012). There is wide inter- and intra-specific variation in morphology and colouration, particularly amongst Rhynchobatus. Examples from developing world fisheries include the presence of cryptic, sympatric species (e.g. Henderson et al. 2016) and considerable within-species variability in dorsal colouration and morphology (Giles et al. 2016). Even apparently well-managed fisheries in the developed world may pose risks to sustainability due to the presence of undistinguishable sympatric taxa. Prior to recent taxonomic clarification, a species complex considered at the time to comprise at least 3 species of Rhynchobatus that could not be reliably separated in the field were managed as a single group in Queensland, Australia, despite there being a difference of $2 \mathrm{~m}$ between the maximum known TL of the smallest and largest species (White et al. 2014a). Significant variation in colouration in guitarfishes has also led to erroneous designation of species, with the magpie fiddler ray Trygonorrhina melaleuca in South Australia, previously thought to be rare and Endangered, recently demonstrated as being a rare colour 
variant of the common and widespread T. dumerilii (Donnellan et al. 2015). These authors also provided evidence of hybridisation, rarely reported in chondrichthyans, adding further complexity to identification in the field.

While the highly distinctive rostrum and sometimes huge size of sawfishes may be a disadvantage in terms of entanglement risk, it may actually benefit sawfishes in some ways. Amidst a plethora of organisms in need of saving from extinction, the rostrum provides an unmistakeable 'personality', a unique selling point to the public and potential funders of research and conservation. The memorable nature of sawfish, and the fact their rostra are retained as tangible evidence of their existence, has also been shown as being valuable in identifying former abundance, distribution and potentially important locations in which to target conservation efforts (Leeney \& Poncelet 2015, Moore 2015). The lack of a unique feature in guitarfishes is therefore unlikely to assist in conservation efforts.

\section{IUCN RED LIST ASSESSMENTS}

A total of 55 species of guitarfish are currently recognised (Table 1), although up to 3 further new species are awaiting description (W. White pers. comm.). At the time of writing (1 March 2017), 49 species have publically available RL assessments (Table 1). The age, and therefore the validity, of global RL assessments varies widely, with assessments performed from 2003 until 2015. Nearly $60 \%$ (28 species) of assessments are out of date (2007 or before). At a family level (excluding species that are Not Evaluated or Data Deficient) the Rhinidae and Glaucostegidae are both notable in that $100 \%$ of species are in threatened categories, compared to only $19 \%$ of the Rhinobatidae and $33 \%$ of the Trygonorrhinidae. Of the 49 species that have been assessed, 20 species $(41 \%)$ are in threatened categories, comprising $1(2 \%)$ Critically Endangered species, $3(6 \%)$ Endangered species and 16 (33\%) Vulnerable species. A further 7 species (14\%) are Near Threatened, while 15 species $(31 \%)$ are currently assessed as Data Deficient. Only a relatively small proportion of guitarfishes are currently assessed as Least Concern (7 species, $14 \%$ ). In addition, 6 recently described taxa have not yet been subject to RL assessments and are Not Evaluated, although these are currently being progressed (P. Kyne, IUCN Shark Specialist Group Red List Authority, pers. comm.). Examples of each of the categories are discussed below.
Critically Endangered. The Brazilian guitarfish Pseudobatos horkelii is currently the only guitarfish classed as Critically Endangered, based on an assessment in 2007 (Lessa \& Vooren 2016). This mediumsized species (maximum recorded TL $1.42 \mathrm{~m}$ ) has a centre of distribution in southern Brazil and was abundant in the 1980s, but suffered severe declines in abundance due to intensive fisheries, particularly due to trawling in areas important for reproduction (Lessa \& Vooren 2016). Although protected, this species continues to be illegally landed by fishers (Alexandre de-Franco et al. 2012).

It is highly likely that updating assessments will identify other guitarfishes as Critically Endangered. This is particularly the case for species that represent the 'perfect storm' of extinction risk of being large, having very high value fins and occurring largely or solely in LDCs with high levels of unregulated or unsustainable fisheries activity (e.g. African wedgefish Rhynchobatus luebberti; see 'Endangered' below), especially when they have extremely restricted known distributions (e.g. Rhynchorhina mauriteniensis).

Endangered. Global assessments for all 3 Endangered species (G. cemiculus, common guitarfish Rhinobatos rhinobatos, Rhynchobatus luebberti) were made in 2006 or 2007 and are out of date. All 3 species have significant parts of their distribution along the coastlines of the West Africa LDC region. Both G. cemiculus and $R$. rhinobatos appear to have disappeared from the northern Mediterranean, and $G$. cemiculus has undergone declines in abundance and size reductions in West Africa (Notarbartolo di Sciara et al. 2007, 2016). In The Gambia, G. cemiculus continues to be targeted for fins and meat for salting and drying, and R. rhinobatos is also landed as bycatch (author's unpubl. data). Deserving of special mention is $R$. luebberti: the only member of its genus to occur in the Atlantic, this large species ( $3 \mathrm{~m} \mathrm{TL}$ ) has a reported range from Mauritania to Angola (Compagno \& Marshall 2006b). Along with sawfishes, $R$. luebberti has been reported as having disappeared from a vast West African region encompassing the coasts of Mauritania to Sierra Leone (Diop \& Dossa 2011), and an authority on the regional elasmobranch fauna does not know of any recent records (B. Séret pers. comm. September 2016). Annual surveys of fish landing and processing sites in The Gambia from 2010 to 2016 have not recorded this species, despite other guitarfish species (G. cemiculus and R. rhinobatos) and other batoids being commonly recorded (author's unpubl. data). A relatively recent record is of a $1.6 \mathrm{~m}$ TL specimen (Fig. 3) caught by recreational angling in Rubane Island, Bijagos archipel- 
ago, Guinea Bissau, in 2006. The captor, an angling guide, reported the capture as 'very, very rare', and also that this species was not caught in Gabon where he had spent time (O. Charpentier pers. comm. July 2016). As such, and especially given that the last RL assessment was in 2006, $R$. luebberti is likely to be a strong candidate for re-assessment as Critically Endangered.

Vulnerable. Most Vulnerable guitarfish assessments are out of date, from 2007 or before (Table 1), and it is unlikely that the situation has improved for many species, as most have all or most of their range in developing countries or LDCs. The majority of Glaucostegidae and Rhinidae are classed as Vulnerable, including Rhina ancylostoma. This distinctive species is distributed across the Indo-West Pacific, where it occurs in fisheries (e.g. White \& Dharmadi 2007, Moore et al. 2012), is popular as a marine aquaria exhibit (Georgia Aquarium 2016), has very high value fins and is the subject of trade in jewellery made from its thorns (M. McDavitt pers. comm.). Yet a search on ISI Web of Science shows the existence of more peer-reviewed research on the parasite fauna of $R$. ancylostoma (e.g. Bullard \& Dippenaar 2003) than the single ecological study relevant to its conservation, of which it was not even the main focus (White et al. 2013a). The clown wedgefish Rhynchobatus cooki, assessed as Vulnerable in 2006 before its very recent description, is only known from a

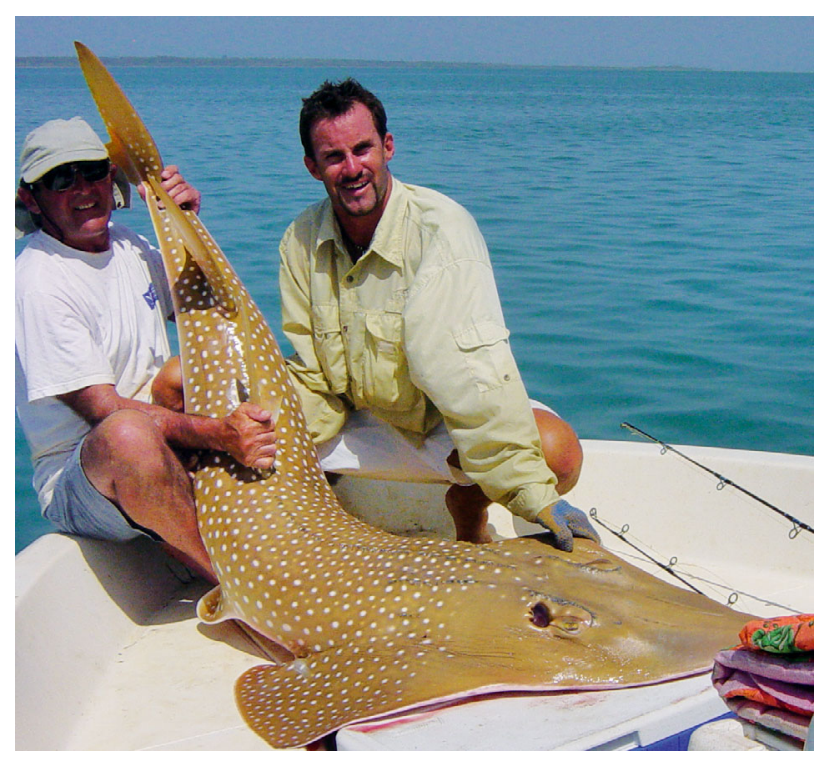

Fig. 3. African wedgefish Rhynchobatus luebberti caught by recreational angling in Bijagos archipelago, Guinea Bissau, in 2006. This species is currently considered Endangered and has been reported as having disappeared from a vast area of West Africa handful of specimens collected in Southeast Asia, and has not been recorded since 1996 (Last et al. 2016c).

Near Threatened. Notably, all but one of the Near Threatened assessments are out of date, from 2007 or before, and include species known from only a few specimens. The Zanzibar guitarfish Acroteriobatus zanzibarensis is a large ( $\geq 2.05 \mathrm{~m} \mathrm{TL}$ ) species known only from the type specimens and apparently endemic to Zanzibar, which lies within the SW Indian Ocean LDC region (Burgess \& Marshall 2016). Similarly, the bareback shovelnose ray Rhinobatos nudidorsalis is known only from the holotype, collected from a seamount in the Western Indian Ocean (Compagno \& Marshall 2006a).

Least Concern. Just $14 \%$ of assessed guitarfish species are considered as Least Concern, and it is notable that 5 of the 7 species (goldeneye shovelnose ray $R h i-$ nobatos sainsburyi, southern fiddler ray Trygonorrhina dumerilii, eastern fiddler ray $T$. fasciata, eastern shovelnose ray Aptychotrema rostrata, western shovelnose ray Aptychotrema vincentiana) are endemic to Australian waters, where fisheries are generally wellregulated with high enforcement capacity (White \& Kyne 2010). The 2 remaining species (lesser sand shark Acroteriobatus annulatus and bluntnose guitarfish Acroteriobatus blochii) occur in southern Africa, and are old assessments that require updating.

Data Deficient. All but one Data Deficient species occur in the Northern and Western Indian Ocean or the Eastern Pacific, making these areas a clear priority for research. Data Deficient species include those that occur regularly in intensively fished areas: since assessment in 2008 (Barnett et al. 2016), the large ( $\geq 1.87 \mathrm{~m}$ TL) Halavi's guitarfish Glaucostegus halavi has been recorded in landings in the Persian Gulf, Red Sea and Gulf of Aden (Moore et al. 2012, Moore \& Peirce 2013, Spaet \& Berumen 2015, author's unpubl. data) (Fig. 4). Conversely, some species remain very poorly known. The Gorgona guitarfish Pseudobatos prahli from the Eastern Pacific was only known from 3 specimens upon RL assessment in 2007 (Kyne 2016), and only a handful have been reported since (Payan et al. 2010, Carrera-Fernandez et al. 2012).

Not Evaluated. A total of 6 recently described species have not yet been subject to assessments against the IUCN RL categories and criteria. Most notable is Rhynchorhina mauritaniensis, a large (at least $2.75 \mathrm{~m}$ TL) species from an entirely new genus known only from Mauritania where targeted fisheries and processing of guitarfishes takes place (Diop \& Dossa 2011, Séret \& Naylor 2016). The Oman guitarfish 


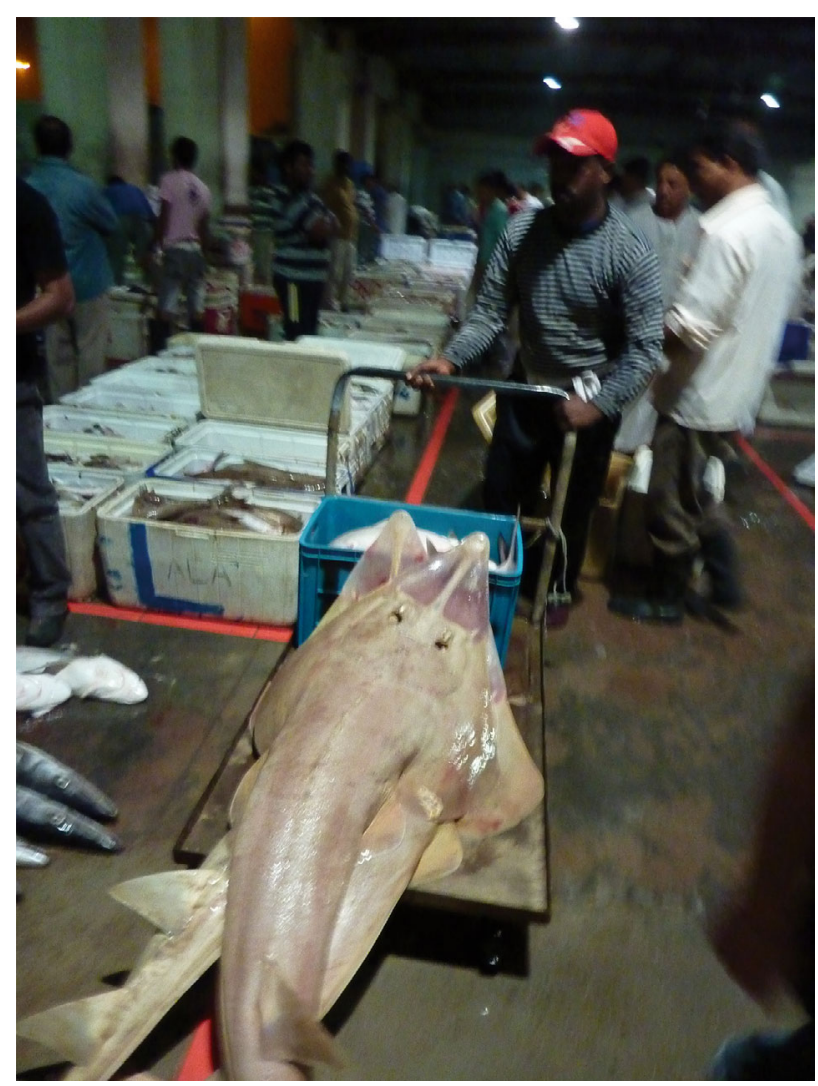

Fig. 4. Large Halavi's guitarfish Glaucostegus halavi, a Data Deficient species, in Manama fish market, Bahrain, April 2012

Acroteriobatus omanensis is known only from a handful of specimens from the Gulf of Oman (Last et al. 2016d), and the Philippine guitarfish Rhinobatos whitei and Borneo shovelnose ray Rhinobatos borneensis are from intensively fished areas (Last et al. 2014, 2016a). The IUCN Shark Specialist Group is currently in the process of assessing these species (P. Kyne pers. comm.). In addition to these newly described guitarfish species, there may be at least 3 more awaiting description (W. White pers. comm.), which will also require RL assessments in the future.

\section{DISCUSSION}

This review has demonstrated that both sawfishes and guitarfishes are exposed to similar vulnerabilities of shallow, soft-sediment coastal habitat accessible to intensive fisheries, often large size and high economic value. While sawfishes are exposed to extinction risk factors that guitarfishes are not (valuable rostra highly prone to entanglement, huge size and reliance on freshwater habitat of some species), the distribution of some species of guitarfishes may render them much more susceptible to total global extinction than any of the sawfish species. Furthermore, many guitarfish species are hindered by problematic identification, and, as indicated by often outdated RL assessments, the vast majority of guitarfishes are threatened, poorly known or both.

It would be comforting to think that directing conservation effort towards guitarfishes now could prevent any of the severe declines and localised extinctions seen for sawfishes, but declines have already occurred in numerous locations. As noted, 2 formerly abundant species (Rhinobatos rhinobatos, Glaucostegus cemiculus) in the northern Mediterranean have now disappeared (Notarbartolo di Sciara et al. 2007, 2016), as has Rhynchobatus luebberti in much of West Africa (Compagno \& Marshall 2006b, Diop \& Dossa 2011). There was evidence of the near complete disappearance of formerly abundant shovelnose guitarfish Pseudobatos productus in Elkhorn Slough, California, USA, by the 1970s, the reasons for which remain unclear (Carlisle et al. 2007). More anecdotal sources suggest that declines of guitarfishes are common, such as of Rhynchobatus djiddensis off Madagascar (Hopkins 2011), and of R. djiddensis and Rhina ancyclostoma off Mozambique, where these were reportedly abundant prior to fisheries commencing in the early 2000s (Pierce et al. 2008). In 2014, an elderly fisherman in the Dhofar region of southern Oman lamented the disappearance of large Rhynchobatus to the author.

As noted above, acknowledgement of past failure is important in advancing future conservation efforts. So what could have been done better for sawfishes, and how can this be applied to guitarfishes? Firstly, severe sawfish declines may have been at least partially ameliorated with a comprehensive and prompt response to known vulnerability and rumoured extinctions, yet it took 3 decades for a coordinated response. The vulnerability of guitarfishes has previously been identified (White et al. 2013b, Dulvy et al. 2014, Lessa \& Vooren 2016), and there is already some evidence of severe declines and localised extinctions: comprehensive and coordinated action is therefore needed urgently.

Secondly, an almost total lack of accessible sawfish distribution and relative abundance data in most of their range prevented identification or monitoring of declines. It is therefore essential that scientists and managers review both existing historic fisherydependent and fishery-independent datasets specifically for guitarfishes, and ensure robust species-specific data are collected in new or ongoing programs, 
particularly for threatened, Data Deficient and Not Evaluated species.

Thirdly, while recent focused first-hand field studies of sawfishes in the USA and Australia have advanced our understanding of spatial ecology (e.g. through tagging) and sensitivities (e.g. nursery areas) that are critical to conservation efforts (e.g. Simpfendorfer et al. 2010, Morgan et al. 2015), this information is still largely lacking for vast areas of the developing world. Very little is known about the spatial ecology of guitarfishes to inform conservation, and what is known is largely limited to the developed world (Farrugia et al. 2011, White et al. 2014b). In addition to the potential to provide significant economic benefits to local communities in LDCs (Potts et al. 2009), recreational fisheries may offer opportunities for gaining crucial knowledge of guitarfish spatial ecology, particularly for larger species that may be both the most threatened and the most attractive to anglers. Over 6000 Acroteriobatus annulatus were tagged in South African sport fisheries between 1984 and 2011, revealing important information such as a maximum distance travelled of $726 \mathrm{~km}$. Yet the tagging of this species was discouraged from 1998 onwards due to it being considered a low research priority (Dunlop et al. 2013).

Finally, it will be important to address taxonomic bias by elasmobranch researchers, funding bodies and conference organisers. The historic and current lack of research on sawfishes and guitarfishes, respectively, may at least partly be due to a bias in elasmobranch research that favours a tiny minority of fearsome and handsome shark species over batoids (Huveneers et al. 2015). Encouragingly, this has been partly redressed with recent coordinated conservation focuses on sawfishes (Harrison \& Dulvy 2014) and devil rays (Lawson et al. 2016), although it is worth noting that both of these groups are perhaps the most highly charismatic of all batoids, being highly recognisable, often large and with strong cultural associations. Engaging researchers and the public alike in less charismatic taxa like guitarfishes will require innovative and collaborative approaches. For example, students of global communications were recently involved in an international competition to develop a winning public relations strategy for dugong and seagrass conservation (Emirates News Agency 2016).

It is not the intention of this paper to list a multitude of research and conservation recommendations, but to highlight the very clear imperative for an urgent, coordinated and comprehensive response for guitarfishes. Based on their large size, high value fins and existing threatened status, the Rhinidae and Glaucostegidae should be among the key priorities. The imperative for action is doubly pressing given the precedent of a collective failure to address catastrophic sawfish declines in most of their global range. Given shared habitat and vulnerabilities, there may be significant opportunities for cost-effective conservation of both sawfishes and guitarfishes, with efforts for the latter offering benefits to the often much rarer former that might otherwise preclude focused conservation attention and funding. However, the inefficiencies of conservation devoted to single taxa such as guitarfish (or elasmobranchs more widely) should be better acknowledged and addressed, when conservation resources are limited and inshore fisheries threaten a myriad of other threatened vertebrates such as teleosts, turtles, dugongs and cetaceans. Updating of RL assessments (and performing them for Not Evaluated species) is an ongoing process that will be essential as a first step for coordinated guitarfish conservation. Research on biological and ecological aspects such as life history and spatial ecology will play a role in our understanding of some guitarfish species, as will use of state-of-the-art techniques such as environmental DNA to locate rare species (Simpfendorfer et al. 2016). Research should acknowledge the hotspots for Data Deficient guitarfish species identified in this study (i.e. North and Western Indian Ocean, Eastern Pacific). However, it is important to acknowledge the significant limitations of research in itself for conservation purposes, particularly in the socio-political realities of very poor coastal human communities facing food security issues that exist alongside some of the most threatened guitarfishes. As noted, total extinction of some guitarfish species is plausible, especially where endemism overlaps with LDC regions, and these should be a key priority for action. Innovative approaches to guitarfish-and wider elasmobranch - conservation in inshore areas of the developing world will be required. While a solid foundation of biological knowledge of elasmobranchs in these areas has been gained in recent decades, human and economic aspects of their fisheries remain disproportionately poorly understood, yet will need to be at the core of any conservation efforts. In this sense, the young movement of elasmobranch conservation may have much to learn from the decades of successes and failures of terrestrial conservation.

Note added in proof. A new species of guitarfish has just been described (Ebert \& Gon 2017). 
Acknowledgements. Gregg Poulakis, Dean Grubbs and many others are thanked for organising both the sawfish symposium in New Orleans (July 2016) and this subsequent Theme Section. For helpful discussions and information the author is grateful to many, including Amie Brautigam, Shelley Clarke, Geremy Cliff, Nicholas Dulvy, Stuart Dunlop, Jenny Giles, Taylor Gorham, Peter Kyne, Matthew McDavitt, Gavin Naylor, Bernard Séret, Simon Weigmann and William White. Michael Burgass provided valuable comments on an earlier draft. The editor and reviewers are thanked for comments which greatly improved the manuscript. The opinions expressed in this paper do not necessarily represent the view of the author's employer.

\section{LITERATURE CITED}

African Dive Adventures (2014) Guitarfish (Rhynchobatus djiddensis). www.afridive.com (accessed 24 September 2016)

Agbesi MPK, Naylor S, Perkins E, Borsuk HS and others (2016) Complex flow in the nasal region of guitarfishes. Comp Biochem Physiol A Mol Integr Physiol 193:52-63

Alexandre de-Franco B, Mendonça FF, Oliveira C, Foresti F (2012) Illegal trade of the guitarfish Rhinobatos horkelii on the coasts of central and southern Brazil: genetic identification to aid conservation. Aquatic Conserv: Mar Freshw Ecosyst 22:272-276

Anonymous (1996) Request for information on sawfishes, family Pristidae. Shark News 6:2

* Barnett LAK, Ebert DA, Henderson A (2016) Glaucostegus halavi. The IUCN Red List of Threatened Species: e. T161408A104013494. http://dx.doi.org/10.2305/IUCN.UK. 2016-3.RLTS.T161408A104013494.en (accessed 1 March 2017)

Blanco-Parra M, Galván-Magaña F, Márquez-Farías JF, Niño-Torres CT (2012) Feeding ecology and trophic level of the banded guitarfish, Zapteryx exasperata, inferred from stable isotopes and stomach contents analysis. Environ Biol Fishes 95:65-77

Borrell A, Cardona L, Kumarran RP, Aguilar A (2011) Trophic ecology of elasmobranchs caught off Gujarat, India, as inferred from stable isotopes. ICES J Mar Sci 68: $547-554$

Bullard SA, Dippenaar SM (2003) Branchotenthes robinoverstreeti n. gen. and n. sp. (Monogenea: Hexabothriidae) from gill filaments of the bowmouth guitarfish, Rhina ancylostoma (Rhynchobatidae), in the Indian Ocean. J Parasitol 89:595-601

Burgess GH, Marshall AD (2016) Acroteriobatus zanzibarensis. The IUCN Red List of Threatened Species: e. T60176A103930955. http://dx.doi.org/10.2305/IUCN.UK. 2016-3.RLTS.T60176A103930955.en (accessed 1 March 2017)

Campagne CS, Sallesb JM, Boisseryc P, Detera J (2015) The seagrass Posidonia oceanica: ecosystem services identification and economic evaluation of goods and benefits. Mar Pollut Bull 97:391-400

Carlisle A, King A, Cailliet GM, Brennan JS (2007) Longterm trends in catch composition from elasmobranch derbies in Elkhorn Slough, California. Mar Fish Rev 69: 25-45

Carlson J, Wiley T, Smith K (2013) Pristis pectinata. The IUCN Red List of Threatened Species: e.T18175A43398238. http://dx.doi.org/10.2305/IUCN.UK.2013-1.RLTS.T18175 A43398238.en (accessed 1 March 2017)

Carrera-Fernandez M, Galvan-Magana F, Escobar-Sanchez
O (2012) First record of Gorgona guitarfish Rhinobatos prahli from the Gulf of Tehauntepec, Mexican Pacific. Mar Biodivers Rec 5:e6

* Casper BM, Ebert DA, Kyne PM (2009) Zapteryx xyster. The IUCN Red List of Threatened Species: e.T60178 A12302031. http://dx.doi.org/10.2305/IUCN.UK.2009-2. RLTS.T60178A12302031.en (accessed 1 March 2017)

* Clarke SC, Milner-Gulland EJ, Cemare TB (2007) Social, economic, and regulatory drivers of the shark fin trade. Mar Resour Econ 22:305-327

Cliff G (1995) Sharks caught in the protective gill nets off Kwazulu-Natal, South Africa. 8. The great hammerhead shark Sphyrna mokarran (Ruppell). S Afr J Mar Sci 15: 105-114

Cliff G, Dudley SFJ (1991) Sharks caught in the protective gill nets off Kwazulu-Natal, South Africa. 4. The bull shark Carcharhinus leucas Valenciennes. S Afr J Mar Sci 10:253-270

* Compagno LJV, Marshall AD (2006a) Rhinobatos nudidorsalis. The IUCN Red List of Threatened Species: e.T60169A12316187. http://dx.doi.org/10.2305/IUCN. UK.2006.RLTS.T60169A12316187.en (accessed 1 March 2017)

* Compagno LJV, Marshall AD (2006b) Rhynchobatus luebberti. The IUCN Red List of Threatened Species: e. T60180A12303076. http://dx.doi.org/10.2305/IUCN. UK.2006.RLTS.T60180A12303076.en (accessed 1 March 2017)

Cripps G, Harris A, Humber F, Harding S, Thomas T (2015) A preliminary value chain analysis of shark fisheries in Madagascar. Indian Ocean Commission report IOTCWPEB11-17

* D'Anastasi B, Simpfendorfer C, van Herwerden L (2013) Anoxypristis cuspidata. The IUCN Red List of Threatened Species: e.T39389A18620409. http://dx.doi.org/ 10.2305/IUCN.UK.2013-1.RLTS.T39389A18620409.en (accessed 1 March 2017)

Diop M, Dossa J (2011) 30 years of shark fishing in West Africa. FIBA/Condé-sur-Noireau

* Donnellan SC, Foster R, Junge C, Huveneers C, Rogers P, Kilian A, Bertozzi T (2015) Fiddling with the proof: the Magpie Fiddler Ray is a colour pattern variant of the common Southern Fiddler Ray (Rhinobatidae: Trygonorrhina). Zootaxa 3981:367-384

* Duke NC, Meynecke JO, Dittman S, Ellison AM and others (2007) A world without mangroves? Science 317:41-42

* Dulvy NK, Fowler SL, Musick JA, Cavanagh RD and others (2014) Extinction risk and conservation of the world's sharks and rays. eLife 3:e00590

* Dulvy NK, Davidson LNK, Kyne PM, Simpfendorfer CA, Harrison LR, Carlson JK, Fordham SV (2016) Ghosts of the coast: global extinction risk and conservation of sawfishes. Aquatic Conserv: Mar Freshw Ecosyst 26:134-153

Dunlop SW, Mann BQ, van der Elst RP (2013) A review of the Oceanographic Research Institute's cooperative fish tagging project: 27 years down the line. Afr J Mar Sci 35: 209-221

*Eebert DA (1991) Diet of the seven gill shark Notorynchus cepedianus in the temperate coastal waters of southern Africa. S Afr J Mar Sci 11:565-572

Ebert DA, Gon O (2017) Rhinobatos austini n. sp., a new species of guitarfish (Rhinopristiformes: Rhinobatidae) from the Southwestern Indian Ocean. Zootaxa 4276 (2): $204-214$

* Emirates News Agency (2016) 14th Annual Global Communication Conference on dugongs, seagrass kicks off at Zayed University. http://wam.ae/en/details/139529580 
1230 (accessed 21 February 2017)

FAO (2016) Fisheries Global Information System (FIGIS) query. www.fao.org/fishery/figis/en (accessed 1 May 2016)

Farrugia TJ, Espinoza M, Lowe CG (2011) Abundance, habitat use and movement patterns of the shovelnose guitarfish (Rhinobatos productus) in a restored southern California estuary. Mar Freshw Res 62:648-657

Georgia Aquarium (2016) Bowmouth guitarfish (Rhina ancylostoma). www.georgiaaquarium.org/animal-guide/ georgia-aquarium/home/galleries/ocean-voyager/galleryanimals/bowmouth-guitarfish (accessed 23 September 2016)

Giles JL, Riginos C, Naylor GJP, Dharmadi, Ovenden JR (2016) Genetic and phenotypic diversity in the wedgefish Rhynchobatus australiae, a threatened ray of high value in the shark fin trade. Mar Ecol Prog Ser 548:165-180

Harris SA, Bennett BA, Branch GM (1988) An assessment of the role of the sand shark Rhinobatos annulatus as a predator in Langebaan Lagoon. S Afr J Mar Sci 7:153-159

Harrison LR, Dulvy NK (2014) Sawfish: a global strategy for conservation. International Union for the Conservation of Nature Species Survival Commission's Shark Specialist Group, Vancouver

Henderson AC, Reeve AJ, Jabado RW, Naylor GJP (2016) Taxonomic assessment of sharks, rays and guitarfishes (Chondrichthyes: Elasmobranchii) from south-eastern Arabia, using the NADH dehydrogenase subunit 2 (NADH2) gene. Zool J Linn Soc 176:399-442

Herre AWCT (1954) The guitarfishes, family Rhinobatidae, of the Philippines and adjacent seas. Philipp J Sci 83: 381-399

Holmes BH, Steinke D, Ward RD (2009) Identification of shark and ray fins using DNA barcoding. Fish Res 95: $280-288$

Hopkins C (2011) External actors, high value resources and threatened species: shark fin commodity chains of Northern Madagascar, interception for conservation. MSc dissertation, Imperial College London

Hutchings JA, Reynolds JD (2004) Marine fish population collapses: consequences for recovery and extinction risk. Bioscience 54:297-309

* Huveneers C, Ebert DA, Dudley SFJ (2015) The evolution of chondrichthyan research through a metadata analysis of dedicated international conferences between 1991 and 2014. Afr J Mar Sci 37:129-139

Inger R, Gregory R, Duffy JP, Stott I, Vorisek P, Gaston KJ (2015) Common European birds are declining rapidly while less abundant species' numbers are rising. Ecol Lett 18:28-36

IUCN (2016) The IUCN Red List of Threatened Species. Version 2016-3. www.iucnredlist.org (accessed 1 March 2017)

IUCN Species Survival Commission (2016) Rules of procedure IUCN Red List assessment process 2013-2016. http: //cmsdocs.s3.amazonaws.com/keydocuments/Rules\%20 of \% 20Procedure \%20for\%20Red\%20List_2013-2016.pdf (accessed 23 February 2017)

James PSBR (1973) Sharks, rays and skates as a potential fishery resource off the east coast of India. Proceedings of the symposium on living resources of the seas around India. Special Publication Central Marine Fisheries Research Institute, Cochin, p 483-494

Keong CH (1996) Shark fisheries and trade in sharks and shark products in Southeast Asia. TRAFFIC, Petaling Jaya

Knight AT (2009) Is conservation biology ready to fail? Conserv Biol 23:517

Kyne PM (2016) Pseudobatos prahli. The IUCN Red List of
Threatened Species: e.T63158A104002851. http://dx.doi. org/10.2305/IUCN.UK.2016-3.RLTS.T63158A104002851. en (accessed 1 March 2017)

Kyne PM, Bennett MB (2002) Diet of the eastern shovelnose ray, Aptychotrema rostrata (Shaw \& Nodder, 1794), from Moreton Bay, Queensland, Australia. Mar Freshw Res 53:679-686

Kyne PM, Carlson J, Smith, K (2013a) Pristis pristis. The IUCN Red List of Threatened Species: e.T18584848A186 20395. http://dx.doi.org/10.2305/IUCN.UK.2013-1.RLTS. T18584848A18620395.en (accessed 1 March 2017)

Kyne PM, Rigby C, Simpfendorfer C (2013b) Pristis clavata. The IUCN Red List of Threatened Species 2013: e.T393 90A18620389. http://dx.doi.org/10.2305/IUCN.UK.20131.RLTS.T39390A18620389.en (accessed 1 March 2017)

* Last PR, Marshall LJ (2006) Urolophus javanicus. The IUCN Red List of Threatened Species: e.T60095A12247760. http://dx.doi.org/10.2305/IUCN.UK.2006.RLTS.T60095A 12247760.en (accessed 1 March 2017)

* Last PR, Corrigan S, Naylor GJP (2014) Rhinobatos whitei (Batoidea: Rhinobatidae) from the Philippine Archipelago. Zootaxa 3872:31-47

* Last PR, Séret B, Naylor GJP (2016a) A new species of guitarfish, Rhinobatos borneensis sp. nov. with a redefinition of the family-level classification in the order Rhinopristiformes (Chondrichthyes: Batoidea). Zootaxa 4117: 451-475

Last PR, White WT, de Carvalho MR, Séret B, Stehmann MF, Naylor GJP (2016b) Rays of the world. CSIRO Publishing, Clayton South

Last PR, Kyne PM, Compagno LJV (2016c) A new species of wedgefish Rhynchobatus cooki (Rhinopristiformes, Rhinidae) from the Indo-West Pacific. Zootaxa 4139: 233-247

Last PR, Henderson AC, Naylor GJP (2016d) Acroteriobatus omanensis (Batoidea: Rhinobatidae), a new guitarfish from the Gulf of Oman. Zootaxa 4144:276-286

*Lawson JM, Fordham SV, O'Malley MP, Davidson LNK and others (2016) Sympathy for the devil: a conservation strategy for devil and manta rays. PeerJ 5:e3027

\% Leeney RH, Downing N (2016) Sawfishes in The Gambia and Senegal - shifting baselines over 40 years. Aquatic Conserv: Mar Freshw Ecosyst 26:265-278

* Leeney RH, Poncelet P (2015) Using fishers' ecological knowledge to assess the status and cultural importance of sawfish in Guinea-Bissau. Aquatic Conserv: Mar Freshw Ecosyst 25:411-430

Lessa R, Vooren CM (2016) Pseudobatos horkelii. The IUCN Red List of Threatened Species: e.T41064A103933918. http://dx.doi.org/10.2305/IUCN.UK.2016-3.RLTS.T41064 A103933918.en (accessed 1 March 2017)

*McClenachan L, Cooper AB, Dulvy NK (2016) Rethinking trade-driven extinction risk in marine and terrestrial megafauna. Curr Biol 26:1640-1646

Moore ABM (2015) A review of sawfishes (Pristidae) in the Arabian region: diversity, distribution, and functional extinction of large and historically abundant marine vertebrates. Aquatic Conserv: Mar Freshw Ecosyst 25: 656-677

Moore ABM, Peirce R (2013) Composition of elasmobranch landings in Bahrain. Afr J Mar Sci 35:593-596

* Moore ABM, McCarthy ID, Carvalho GR, Peirce R (2012) Species, size, sex and male maturity composition of previously unreported elasmobranch landings in Kuwait, Qatar and Abu Dhabi Emirate. J Fish Biol 80:1619-1642

*Morgan DL, Allen MG, Ebner BC, Whitty JM, Beatty SJ (2015) Discovery of a pupping site and nursery for criti- 
cally endangered green sawfish Pristis zijsron. J Fish Biol 86:1658-1663

Neat F, Pinto C, Burrett I, Cowie L and others (2015) Site fidelity, survival and conservation options for the threatened flapper skate (Dipturus cf. intermedia). Aquatic Conserv: Mar Freshw Ecosyst 25:6-20

Notarbartolo di Sciara G, Bradai MN, Morey G, Marshall AD and others (2007) Rhinobatos rhinobatos. The IUCN Red List of Threatened Species: e.T63131A12620901. http:// dx.doi.org/10.2305/IUCN.UK.2007.RLTS.T63131A12620 901.en (accessed 1 March 2017)

Notarbartolo di Sciara G, Bradai MN, Morey G, Brahim K and others (2016) Glaucostegus cemiculus. The IUCN Red List of Threatened Species: e.T63132A104009894. http://dx.doi.org/10.2305/IUCN.UK.2016-3.RLTS.T63132 A104009894.en (accessed 1 March 2017)

Payan LF, Mejia-Falla PA, Navia AF, Lozano RA (2010) New records of Gorgona guitarfish Rhinobatos prahli on the Colombian Pacific coast. Mar Biodivers Rec 3:e52

Payne JL, Bush AM, Heim NA, Knope ML, McCauley D (2016) Ecological selectivity of the emerging mass extinction in the oceans. Science 353:1284-1286

Pierce SJ, Trerup M, Williams C, Tilley A, Marshall AD, Raba N (2008) Shark fishing in Mozambique: e preliminary assessment of artisanal fisheries. Eyes on the Horizon, Maputo

*Possingham HP, Andelman SJ, Burgman MA, Medellín RA, Master LL, Keith DA (2002) Limits to the use of threatened species lists. Trends Ecol Evol 17:503-507

Potts WM, Childs AR, Sauer WHH, Duarte ADC (2009) Characteristics and economic contribution of a developing recreational fishery in southern Angola. Fish Manag Ecol 16:14-20

Redford KH, Taber A (2000) Writing the wrongs: developing a fail-safe culture in conservation. Conserv Biol 14: 1567-1568

Roberts CM, Hawkins JP (1999) Extinction risk in the sea. Trends Ecol Evol 14:241-246

Schaeffer D (2004) Assessment of the artisanal shark fishery and local shark fin trade on Unguja Island, Zanzibar. Independent Study Project (ISP) Collection. Paper 536. http://digitalcollections.sit.edu/isp_collection/536

Séret B, Naylor GJP (2016) Rhynchorhina mauritaniensis, a new genus and species of wedgefish from the eastern central Atlantic (Elasmobranchii: Batoidea: Rhinidae). Zootaxa 4138:291-308

Shephard S, Gerritsen H, Kaiser MJ, Reid DG (2012) Spatial heterogeneity in fishing creates de facto refugia for endangered Celtic Sea elasmobranchs. PLOS ONE 7: e49307

* Simpfendorfer C (2013) Pristis zijsron. The IUCN Red List of Threatened Species: e.T39393A18620401. http://dx. doi.org/10.2305/IUCN.UK.2013-1.RLTS.T39393A186204 01.en (accessed 1 March 2017)

Simpfendorfer CA, Wiley TR, Yeiser BG (2010) Improving conservation planning for an endangered sawfish using data from acoustic telemetry. Biol Conserv 143: 1460-1469

Simpfendorfer CA, Kyne PM, Noble TH, Goldsbury J and others (2016) Environmental DNA detects Critically Endangered largetooth sawfish in the wild. Endang Species Res 30:109-116

Spaet JLY, Berumen ML (2015) Fish market surveys indicate unsustainable elasmobranch fisheries in the Saudi
Arabian Red Sea. Fish Res 161:356-364

Suzuki T (2002) Development of shark fisheries and shark fin export in Indonesia: case study of Karangsong village, Indramayu, West Java. In: Fowler SL, Reed TM, Dipper FA (eds) Elasmobranch biodiversity, conservation and management. Proc Int Semin and Workshop. IUCN SSC Shark Specialist Group. IUCN, Gland, p 149-157

Thorson TB (1982) The impact of commercial exploitation on sawfish and shark populations in Lake Nicaragua. Fisheries 7:2-10

* Tomita T, Murakumo K, Miyamoto K, Sato K, Oka SI, Kamisako H, Toda M (2016) Eye retraction in the giant guitarfish, Rhynchobatus djiddensis (Elasmobranchii: Batoidea): a novel mechanism for eye protection in batoid fishes. Zoology 119:30-35

*Uerpmann HP, Uerpmann M (2005) Fish exploitation at Bronze Age harbour sites in the Arabian Gulf area. Paéorient 31:108-115

UNDESA (2016) What are least developed countries? United Nations Development Policy and Analysis Division. www.un.org/development/desa/dpad/least-developedcountry-category.html (accessed 2 September 2016)

V Valiela I, Bowen JL, York JK (2001) Mangrove forests: one of the world's threatened major tropical environments. Bioscience 51:807-815

Vaudo JJ, Heithaus MR (2011) Dietary niche overlap in a nearshore elasmobranch mesopredator community. Mar Ecol Prog Ser 425:247-260

*Waycott M, Duarte CM, Carruthers TJB, Orth RJ and others (2009) Accelerating loss of seagrasses across the globe threatens coastal ecosystems. Proc Natl Acad Sci USA 106:12377-12381

White WT, Dharmadi (2007) Species and size compositions and reproductive biology of rays (Chondrichthyes, Batoidea) caught in target and non-target fisheries in eastern Indonesia. J Fish Biol 70:1809-1837

White WT, Kyne PM (2010) The status of chondrichthyan conservation in the Indo-Australasian region. J Fish Biol 76:2090-2117

White WT, McAuley R (2003) Rhynchobatus australiae. The IUCN Red List of Threatened Species: e.T41853A105 80429. http://dx.doi.org/10.2305/IUCN.UK.2003.RLTS.T4 1853A10580429.en. (accessed 1 March 2017)

White WT, Sommerville E (2010) Elasmobranchs of tropical marine ecosystems. In: Carrier JC, Musick JA, Heithaus MR (eds) Sharks and their relatives II: biodiversity, adaptive physiology and conservation. CRC, Boca Raton, FL, p 159-239

*White J, Simpfendorfer CA, Tobin AJ, Heupel MR (2013a) Application of baited underwater video surveys to quantify spatial distribution of elasmobranchs at an ecosystem scale. J Exp Mar Biol Ecol 448:281-288

White J, Heupel MR, Simpfendorfer CA, Tobin AJ (2013b) Shark-like batoids in Pacific fisheries: prevalence and conservation concerns. Endang Species Res 19:277-284

*White J, Simpfendorfer CA, Tobin AJ, Heupel MR (2014a) Age and growth parameters of shark-like batoids. J Fish Biol 84:1340-1353

*White J, Simpfendorfer CA, Tobin AJ, Heupel MR (2014b) Spatial ecology of shark-like batoids in a large coastal embayment. Environ Biol Fishes 97:773-786

*Wueringer BE, Squire LJ, Collin S (2009) The biology of extinct and extant sawfish (Batoidea: Sclerorhynchidae and Pristidae). Rev Fish Biol Fish 19:445-464

Submitted: October 18, 2016; Accepted: April 6, 2017

Proofs received from author(s): July 10, 2017
Editorial responsibility: Gregg Poulakis (Guest Editor), Port Charlotte, Florida, USA 